\title{
OPEN Morphological, molecular characterization, plant pathogenicity and biocontrol of Cladosporium complex groups associated with faba beans
}

\author{
Eman Gamal Abd Elnaser Mohamed El-Dawy ${ }^{1,2}$, Youssuf Ahmed Gherbawy ${ }^{1,2}$ \& \\ Mohamed Ahmed Hussein ${ }^{1,2}$
}

Vicia faba (faba bean) is one of the most significant leguminous crops. The faba bean is specialized by maximum nutritional value, in energy and protein content, which leads it to be suitable for food and feed production. Diseases caused with fungi are amongst the biotic factors responsible for decreasing in faba bean yields. In this work, Cladosporium isolates were recorded in cultivated faba bean leaves and pods collected from markets in Qena, Upper Egypt; morphological features and molecular characterization based on actin gene were performed. The ability of the pathogens to cause disease in faba bean seedlings and the biocontrol method to avoid the pathogenic effect of Cladosporium were determined. Results showed that Cladosporium is the main genera isolated from faba beans, and the morphological criteria showed presence of three species complex groups of Cladosporium (C. cladosporioides, C. herbarum and C. sphaerospermum) and the confirmation with molecular characterization revealed the existence of four species in the three groups. All the 26 tested strains of Cladosporium were able to cause leaf lesions on Vicia faba seedlings with different levels. Chaetomium globosum is a biocontrol agent could inhibit the growth of the majority strains of Cladosporium.

Vicia faba L. (faba bean) is a main legume species; growing in winter season in the area of North Nile Delta ${ }^{1}$. It has high protein content (24-30\%), nutritional value, and high energy, and the faba bean is grown for animal feed and human food ${ }^{2,3}$. The quality and yield of faba bean seeds are affected by fungal diseases, which are among the biotic factors cause major yield losses in faba beans, by decreasing the growth of plants, in excessive cases leading to wilt and plant death ${ }^{4}$. Some fungal pathogens can cause the closure of seed plantations by epidemic outbreaks ${ }^{5}$.

Cladosporium represents one of the considerable genera of Ascomycota, Pezizomycotina, Dothideomycetes, Pleosporomycetidae, Capnodiales, Cladosporiaceae ${ }^{6}$. It comprises species that are among the most prevalent molds isolated from different environments in the world ${ }^{7}$. Many species are plant pathogens, and others are found as spoilage factors or contaminants in food or industrial products, as well as being frequently associated with asthmatic sickness and endophytic fungi ${ }^{7,8}$.

The genus of Cladosporium comprised three major species complexes, mainly based on morphology: $C$. cladosporioides, C. herbarum and C. sphaerospermum species complexes and used for practical purposes. Morphological features describing the three species complexes have been reported by Bensch et al. ${ }^{9-11}$. Based on the morphology, majority of the Cladosporium species can be referred to one of the three species complexes. Otherwise, many studies led to the introduction of subgenera due to the discovery of three diverse complexes: C. cladosporioides $^{12}$, C. herbarum ${ }^{13}$ and C. sphaerospermum ${ }^{14,15}$, each of complex group comprised species that are differentiated morphologically and genetically. Species appearing clear morphological differences may be belonging to different species complexes and even genetically they are usually discriminated and form separate clades $^{9,16}$. In order to identify and distinguish closely related species that showing similar morphological features, molecular sequences are used to accurate identification. However, ITS sequencing is often not sufficient to differentiate closely related species and morphologically similar within complexes. A few researchers choose

${ }^{1}$ Botany and Microbiology Department, Faculty of Science, South Valley University, Qena, Egypt. ${ }^{2}$ Applied and Environmental Microbiology Center, South Valley University, Qena, Egypt. ${ }^{\square}$ email: eman.mohamed11@ sci.svu.edu.eg 
to use a multilocus DNA sequences dependent on actin, ITS, calmodulin, translation elongation factor 1-a and histone $\mathrm{H} 3$ because they show a high discrimination of closely related species ${ }^{12,13}$.

The aim of this study was to identify of Cladosporium species by morphological characterization and confirmed by molecular sequences, determine the pathogenic effect of Cladosporium isolates on faba beans and apply biocontrol method in order to use preventive measures, so avoid biological damage and economical losses (Supplementary Information).

\section{Materials and methods}

Isolation, and determination of morphological criteria. Leaves and pods of cultivated Vicia faba infected with dark fungi were collected from farms and markets in Qena, Egypt during winter. The dilution- and baiting-plate methods were used for the estimation of mycobiota associated with leaves and pods of Vicia faba as described by Christensen ${ }^{17}$ and employed by Abdel-Hafez et al. ${ }^{18,19}$. In dilution- plate method, one gram of leaf or pod sample was removed, transferred to $100 \mathrm{ml}$ sterile distilled water and shacked by hands for $10 \mathrm{~min}$. One $\mathrm{ml}$ aliquot was inoculated into sterile petri dish, followed by adding $15 \mathrm{ml}$ liquefied DG18 medium (g/l: 10 glucose; 5 peptone; $1 \mathrm{KH}_{2} \mathrm{PO}_{4}$; $0.5 \mathrm{MgSO}_{4}$; 0.002 dichloran; 220 glycerol; 0.025 rosebegal; 0.1 chlorampheni$\mathrm{col})^{20}$. The plates were carefully rotated clockwise and anticlockwise to ensure distribution of homogenates, and then incubated at $28{ }^{\circ} \mathrm{C}$ for 7 days. In baiting-plate method: firstly, the samples were rinsed gently in running water to remove dust and debris. Then, samples were cut into $10 \mathrm{~mm}$ in diameter and dried between sterile filter paper. Finally, four segments were inoculated on DG18 plate. The plates incubated at $28{ }^{\circ} \mathrm{C}$ for 7 days then the developing fungi were counted and identified morphologically based on macro- and microscopic characters on PDA medium according to Bensch et al. ${ }^{9}$.

DNA extraction from Cladosporium isolates. The isolation of DNA from Cladosporium mycelium was carried out according to a CTAB protocol ${ }^{21}$. Isolates were grown on PDA plates for $2-3$ days at $28^{\circ} \mathrm{C}$. The mycelium was collected by using a spatula, milled with $700 \mu \mathrm{l} 2 \mathrm{xCTAB}$ buffer in a mortar, transferred to Eppendorf tubes and vortex for $2 \mathrm{~min}$; incubation at $65^{\circ} \mathrm{C}$ for $60-80 \mathrm{~min}$ was done, and then $700 \mu \mathrm{l}$ of chloroform was mixed briefly. The mixture was centrifuged at $15,000 \mathrm{rpm}$ for $10 \mathrm{~min}$, the supernatant was transferred to a new tube, mixed briefly by $600 \mu \mathrm{l}$ isopropanol, and chilled to $20^{\circ} \mathrm{C}$, followed by another centrifugation at $15,000 \mathrm{rpm}$ for $5 \mathrm{~min}$. The supernatant was removed and the settling pellet was washed by $1000 \mu \mathrm{l}$ of $70 \%$ ethanol; another centrifugation for $3 \mathrm{~min}$ at 15,000 was carried out, drying the pellet and dissolved it in $50 \mu \mathrm{TE}(\mathrm{pH} 7.5: 10 \mathrm{mM}$ Tris, $1 \mathrm{mM}$ EDTA) buffer. The DNA quality was tested by electrophoresis on a $1.4 \%$ agarose gel, which was supplied by ethidium bromide, and visualized by UV trans-illumination.

PCR amplification and sequence analysis. For identifying Cladosporium isolates at species level, PCR amplification of partial gene sequences of the actin gene (ACT) were performed. PCR amplification for ACT gene was carried out by primers ACT-512F: ATGTGCAAGGCCGGTTTCGC and ACT-783R: TACGAGTCC TTCTGGCCCAT ${ }^{9,22}$. PCR was done in PCR tubes containing a total volume of $25 \mu \mathrm{l}: 5 \mu \mathrm{l}$ of the master mix (buffer, dNTP, Taq DNA polymerase, $2 \mathrm{mM} \mathrm{MgCl} 2$ ), $1 \mu$ l of the template DNA, $0.5 \mu$ l of both forward and reverse primers and $18 \mu \mathrm{l}$ of PCR water. Amplification of actin gene was performed in a thermal cycler (Flexigene, Techne, Cambridge, UK). Amplification condition was: initial denaturation step at $95^{\circ} \mathrm{C}$ for 8 min followed by 35 cycles of denaturation at $95^{\circ} \mathrm{C}$ for $30 \mathrm{~s}$, annealing at $48^{\circ} \mathrm{C}$ for $30 \mathrm{~s}$ and extension at $72{ }^{\circ} \mathrm{C}$ for $1 \mathrm{~min}$, with a final extension step at $72^{\circ} \mathrm{C}$ for $5 \mathrm{~min}$. Water was used as a negative control.

Phylogenetic analysis. The sequences of actin gene were edited by Chromas Lite program. The sequence results were compared with other fungal sequences in NCBI's GenBank sequence database to identify species by using a blast search. An alignment of the sequences was carried out with the CLUSTAL W program ${ }^{23}$. Sequences were submitted to GenBank on the NCBI website (http://www.ncbi.nlm.nih.gov). The resulting sequences were deposited in GenBank with accession numbers listed in Table 2. Phylogenetic reconstruction of the partial actin sequences was carried out using MEGA6 software package ${ }^{24}$. Maximum likelihood analyses were conducted using the Tamura-Nei model ${ }^{25}$. To detect the support for each clade, a bootstrap analysis was performed with 1000 replications. Alternaria alternata MK 896856.1 was used as outgroup.

Pathogenicity effect of Cladosporium strains. Twenty-six strains of four species of Cladosporium, collected from diseased leaves and pods of Vicia faba, were tested for their pathogenicity effect on Vicia faba seedlings as method described with Berner et al. ${ }^{26}$. Vicia faba seeds were grown in a glasshouse. Firstly, sandy clay soil was sterilized by using autoclave $1: 2(\mathrm{w} / \mathrm{w})$. Then three $\mathrm{kg}$ of sterilized soil was placed in pots with $200 \mathrm{~mm}$ in diameter. By using $0.1 \%$ mercuric chloride, seed surface was done for 2 min and washed several times with sterile water. Each pot was sown by three seeds and daily irrigated daily by water until seedlings' appearance. Spore suspensions of Cladosporium species strains were used for inoculation of plants. The isolates were cultured on potato dextrose agar medium. The pathogenicity of tested species was assayed after 20 days of seeds grown by spraying of leaves. Three replicates were carried out for each isolate and control plant was sprayed by sterile distilled water. Spots on the leaf surface of plants were recorded after 6-10 days of inoculation.

Inhibition the growth of Cladosporium strains by Chaetomium globosum. Chaetomium globosum (isolated as an endophytic fungus from Ziziphus lotus leaves) was tested for antagonism against Cladosporium strains using the dual culture technique. The culture medium was potato dextrose agar, PDA (g/l: 200 potato; 20 glucose; 15 agar $)^{27}$. The medium was poured into petri dishes. A single disc with $8 \mathrm{~mm}$ of Cladosporium strain 


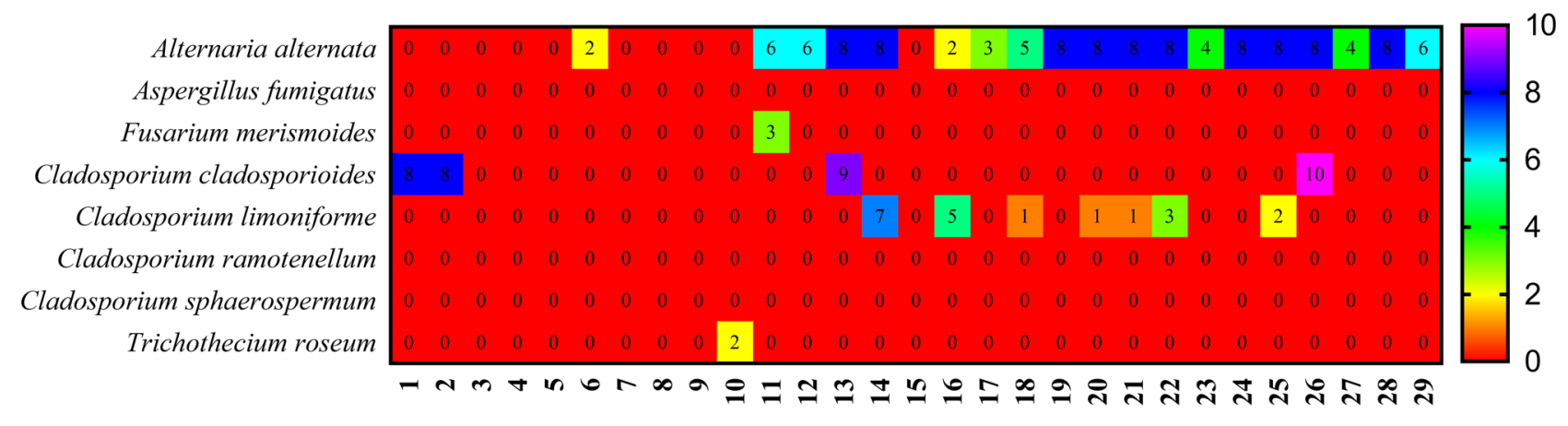

No. of the samples

Figure 1. Fungal counts of species isolated from infected Vicia faba leaves and pods with baiting-plate method on DG18 medium at $28^{\circ} \mathrm{C}$ for 7 days.

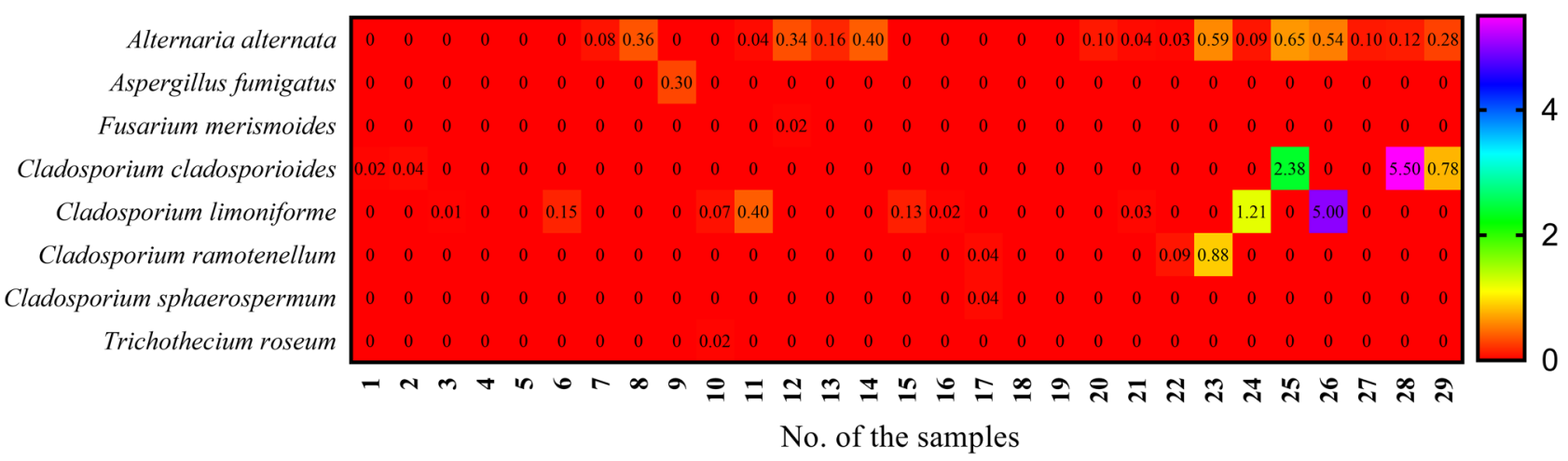

Figure 2. CFU of species isolated from infected Vicia faba leaves and pods with dilution-plate method on $\mathrm{DG} 18$ medium at $28^{\circ} \mathrm{C}$ for 7 days.

and C. globosum colonies were plated in the same petri dish. The plates were incubated at $28^{\circ} \mathrm{C}$ for 7 days. Triplicates were used for each Cladosporium isolate. Radial growth reduction was calculated according to the formula of mycelial inhibition $(\%)=\left[\left(r-r^{-}\right) / r\right] \times 100$, where $r(\mathrm{~mm})$ is the growth of Cladosporium from the center of the colony disc towards the edge of the petri dish and $r^{-}(\mathrm{mm})$ is the growth of the Cladosporium from the center of the colony towards the center of the tested C. globosum ${ }^{27}$.

Statistics. Statistical analyses were carried out on repeated measurements by one-way analysis of variance (ANOVA) by using Prism Version 6.0 (GraphPad Software, Inc., San Diego, CA, USA), followed by Bonferroni's multiple comparison test ${ }^{28}$.

Research involving human participants and/or animals. We declare that no human or animal were involved during the research.

Permission statement. This is a permission from South Valley University to collect samples of cultivated faba beans from fields of the South Valley University and markets in Qena, were complied with relevant institutional, national, and international guidelines and legislation and transferring them safely to mycological analysis to South Valley University, Faculty of Science, Botany and Microbiology department, Applied and Environmental Microbiology Center.

\section{Results}

Mycobiota associated with Vicia faba leaves and pods. Twenty-nine samples of leaves and pods of Vicia faba were gathered from various markets and farms in Qena, Egypt. Eight fungal species were isolated from the samples on DG18 medium at $28^{\circ} \mathrm{C}$. Fungal species were recovered from the samples by dilution and baiting-plate methods. The fungal-colony forming unit (CFU) in dilution-plate method was 21.05 colonies/g fresh samples and the fungal total count in baiting-plate method was 178 colonies/232 segments. Five genera comprised a total of eight species were collected from the twenty-nine samples of Vicia faba. Cladosporium cladosporioides species complex was the most common species was isolated from the samples by dilution-plate method with CFU 8.72 colonies/g fresh samples and the highest CFU was estimated in the sample no. 28 with 


\begin{tabular}{|c|c|c|c|c|}
\hline Characteristics & C. cladosporioides & C. limoniforme & C. ramotenellum & C. sphaerospermum \\
\hline \multicolumn{5}{|l|}{ Colony } \\
\hline Color & Grey-olivaceous & $\begin{array}{l}\text { Dull green due to abundant sporula- } \\
\text { tion }\end{array}$ & $\begin{array}{l}\text { Olivaceous due to abundant sporula- } \\
\text { tion }\end{array}$ & Olive-green \\
\hline Texture & $\begin{array}{l}\text { Regular, feathery, white aerial myce- } \\
\text { lium sparse, diffuse, or sometimes } \\
\text { abundantly formed. Margins white to } \\
\text { grey-olivaceous }\end{array}$ & Glabrous. Margins regular, and white & $\begin{array}{l}\text { Margin entire edge to slightly undu- } \\
\text { late, white, glabrous }\end{array}$ & Glabrous. Margins regular, and white \\
\hline Reverse & Olivaceous-black and velvety & Olivaceous black, velvety & Olivaceous black, velvety & Olivaceous black, velvety \\
\hline \multicolumn{5}{|l|}{ Conidia } \\
\hline Shape & $\begin{array}{l}\text { Subglobose, obovoid, ovoid to } \\
\text { limoniform }\end{array}$ & $\begin{array}{l}\text { Catenate, very numerous, ornamenta- } \\
\text { tion variable, obovoid to subglobose, } \\
\text { apex rounded, attenuated towards the } \\
\text { base, ellipsoid, limoniform, sometimes } \\
\text { fusiform }\end{array}$ & $\begin{array}{l}\text { Globose, subglobose or ovoid, } \\
\text { obovoid or limoniform, ellipsoid, } \\
\text { limoniform to subcylindrical }\end{array}$ & $\begin{array}{l}\text { Subspherical to spherical, less often } \\
\text { short-ovoid }\end{array}$ \\
\hline Size $(\mu \mathrm{m})$ & $\begin{array}{l}\begin{array}{l}2.797-13.047 \text { (length) } \times 0.959-3.955 \\
\text { (width) }\end{array} \\
\end{array}$ & $2.797-13.367 \times 2.143-5.928$ & $4.34-10.075 \times 2.581-3.456$ & $4.126-5.468 \times 1.517-4.098$ \\
\hline Septum & $0-1$ & $0-1$ & $0-1$ & 0 \\
\hline \multicolumn{5}{|l|}{ Ramoconidia } \\
\hline Shape & $\begin{array}{l}\text { Ellipsoid, subcylindrical to cylindrical- } \\
\text { oblong }\end{array}$ & $\begin{array}{l}\text { Ellipsoid, fusiform to subcylindrical, } \\
\text { slightly thickened }\end{array}$ & $\begin{array}{l}\text { Ellipsoid, subcylindrical to cylindri- } \\
\text { cal-oblong, sometimes swollen }\end{array}$ & Ellipsoid to cylindrical \\
\hline Size $(\mu \mathrm{m})$ & $\begin{array}{l}\text { 11.4-27.106 (length) } \times 2.035-4.422 \\
\text { (width) }\end{array}$ & $11.391-27.139 \times 2.581-6.453$ & $15.47-30.313 \times 2.396-4.418$ & $16.405-33.153 \times 2.797-4.07$ \\
\hline Septum & $0-1-2-3$ & $0-1-2-3$ & $0-1$ & $0-1$ \\
\hline \multicolumn{5}{|l|}{ Conidiophore } \\
\hline Width $(\mu \mathrm{m})$ & $1.517-5.468$ & $1.918-4.418$ & $3.489-6.1$ & $1.517-6.308$ \\
\hline Chlamydospores & Absent & Present with abudantly & Present with rarley & Absent \\
\hline
\end{tabular}

Table 1. Morphological and cultural characteristics of Cladosporium sp. on PDA medium at $28^{\circ} \mathrm{C}$ for 7 days.

count 5.50 colonies/g fresh samples. Alternaria alternata was the dominant species taking into its counts in baiting-plate method with count 118 colonies/232 segments and the highest counts were estimated in the sample nos. $13,14,19,20,21,22,24,25,26$ and 28. C. cladosporioides species complex ranked the second position in its count in baiting plate method with count 35 colonies / 232 segments and the maximum value was observed in the sample no. 26 (Figs. 1 and 2).

Morphological characterization of Cladosporium sp.. Dependent upon micro- and macroscopical characteristics of the colonies, conidia, ramoconidia and presence or absence of chlamydospores, all the collected Cladosporium isolates were grouped into three groups; C. cladosporioides species complex, C. herbarum species complex and C. sphaerospermum species complex.

Twenty-six isolates were randomly chosen to evaluate the taxonomic description by observing the micro-and macroscopical features as shown in Table 1, and Figs. 3 and 4.

C. cladosporioides species complex. Colony and texture on PDA medium were grey-olivaceous, regular, feathery and white aerial mycelium sparse, diffuse, or sometimes abundantly formed. Margin of the colony was white to grey-olivaceous. Colony reverse was olivaceous-black and velvety. Conidial shapes were subglobose, obovoid, ovoid to limoniform, with size $2.797-13.047 \mu \mathrm{m}$ (length) $\times 0.959-3.955$ (width) and without septa and sometimes one septum was found. Ramoconidia were observed with different shapes; ellipsoid, subcylindrical to cylindrical-oblong, with size 11.4-27.106 $\mu \mathrm{m}$ (length) $\times 2.035-4.422$ (width), had 0-3 septate. Conidiophore was $1.517-5.468 \mu \mathrm{m}$ in width and chlamydospores weren't observed in this species.

C. herbarum species complex (C. limoniforme). C. limoniforme could be identified exactly after confirmation of molecular characterization before that it inserted under the species of $C$. herbarum. Colony and texture on PDA medium were dull green due to expand and abundant sporulation. Glabrous texture was noticed, margins regular, and white. Colony reverse was olivaceous black, velvety. Shapes of conidia were catenate, very numerous, ornamentation variable, obovoid to subglobose, apex rounded, attenuated towards the base, ellipsoid, limoniform, sometimes fusiform. Size of conidia ranged 2.797-13.367 $\mu \mathrm{m}$ (length) $\times 2.143-5.928 \mu \mathrm{m}$ (width), rarely one septum was found. Ramoconidial shapes were ellipsoid, fusiform to subcylindrical, slightly thickened with size 11.391-27.139 $\mu \mathrm{m}$ (length) $\times 2.581-6.453 \mu \mathrm{m}$ (width), $0-3$ septate was observed. Conidiophore was 1.918$4.418 \mu \mathrm{m}$ (width) and chlamydospores were abundantly noticed in all tested isolates.

C. herbarum species complex (C. ramotenellum). C. ramotenellum was identified morphologically under the $C$. herbarum species complex and molecular identification confirmed its name. Colony color was olivaceous due to abundant sporulation. Texture and margin entire edge to slightly undulate, white and glabrous. Reverse color olivaceous black and velvety. Shapes of conidia varied from globose, subglobose or ovoid, obovoid or limoniform, 
1
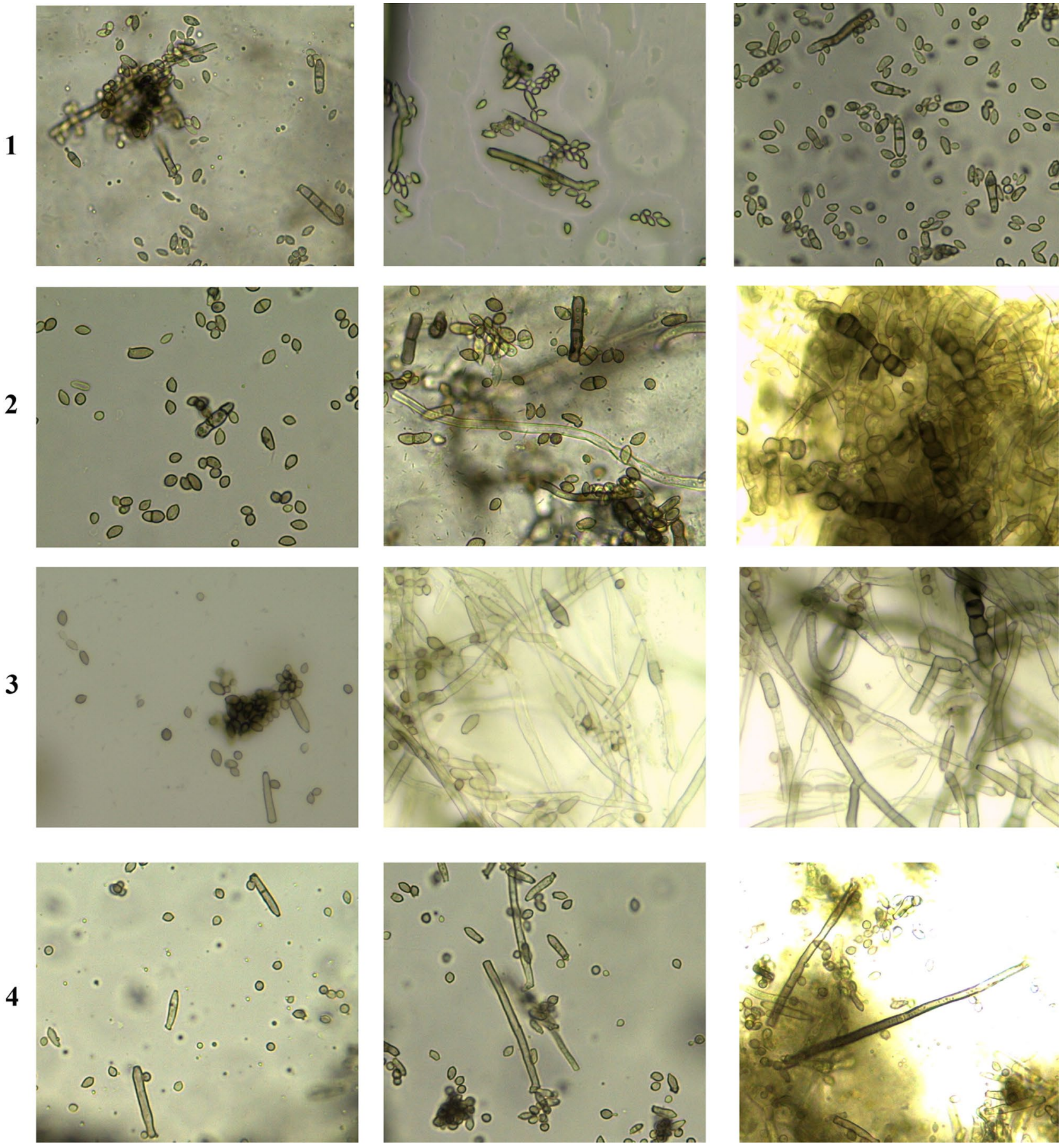

Figure 3. Ramoconidia, conidia, conidiophores and chlamydospores of (1): C. cladosporioides, (2): C. limoniforme, (3): C. ramotenellum and (4): C. sphaerospermum.

ellipsoid, limoniform to subcylindrical, with size 4.34-10.075 $\mu \mathrm{m}$ (length) $\times 2.581-3.456 \mu \mathrm{m}$ (width) and sometimes one septum was observed. Shapes of ramoconidia were ellipsoid, subcylindrical to cylindrical-oblong, sometimes swollen. Ranged in the size from 15.47 to $30.313 \mu \mathrm{m}$ (length) $\times 2.396-4.418 \mu \mathrm{m}$ (width) and $0-1$ septum was found. Conidiophore width was 3.489-6.1 $\mu \mathrm{m}$ and chlamydospores were present with rarley.

C. sphaerospermum species complex. Colony and texture were olive-green, glabrous. Margins regular, and white. Reverse color was olivaceous black, velvety. Conidial shape subspherical to spherical, less often shortovoid. The size of conidia was 4.126-5.468 $\mu \mathrm{m}$ (length) $\times 1.517-4.098 \mu \mathrm{m}$ (width) without septum. Ramoconidia were ellipsoid to cylindrical with size $16.405-33.153 \mu \mathrm{m}$ (length) $\times 2.797-4.07 \mu \mathrm{m}$ (width) and 0-1 septum was found. Conidiophore width was 1.517-6.308 $\mu \mathrm{m}$ (width). Chlamydospores were absent in this species. 


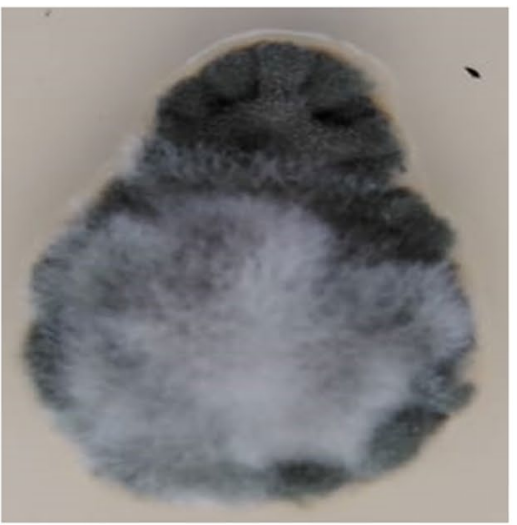

1

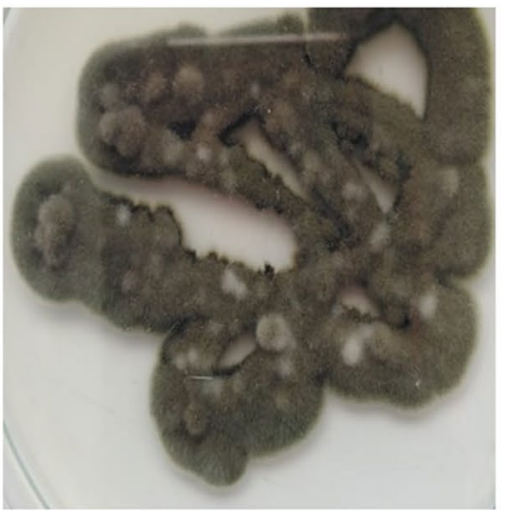

4

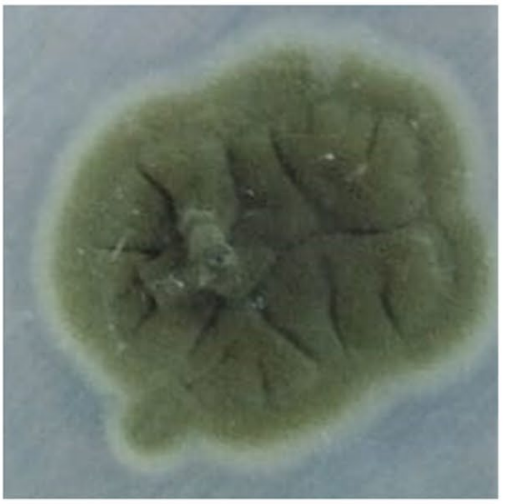

7

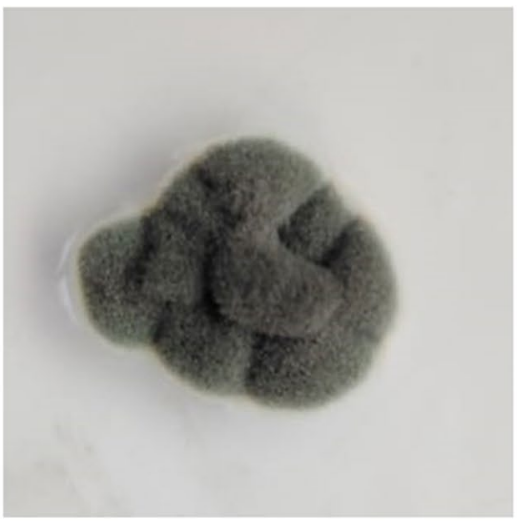

2

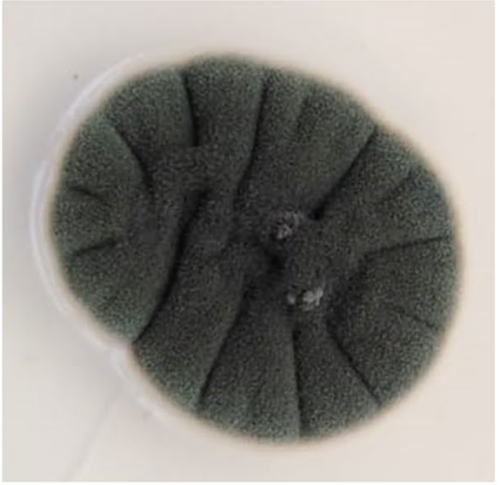

5

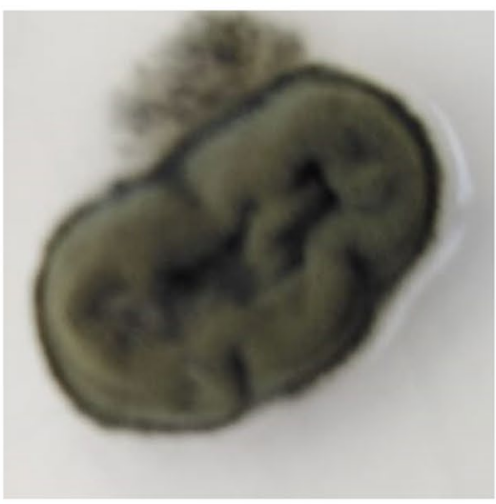

8

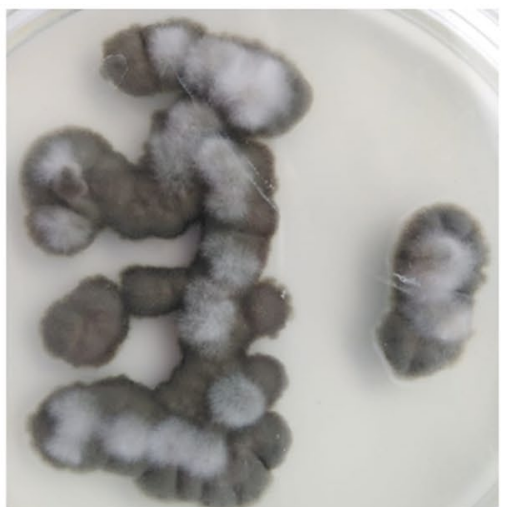

3

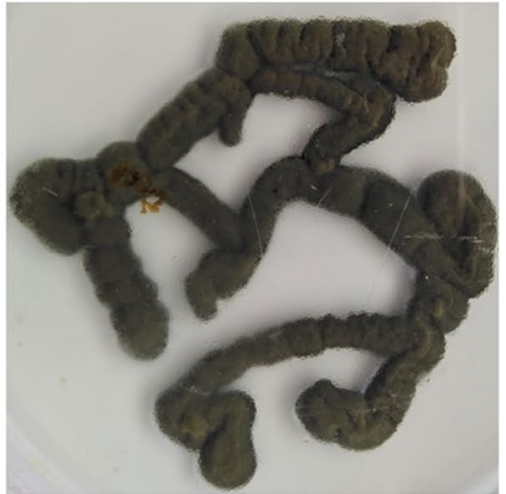

6

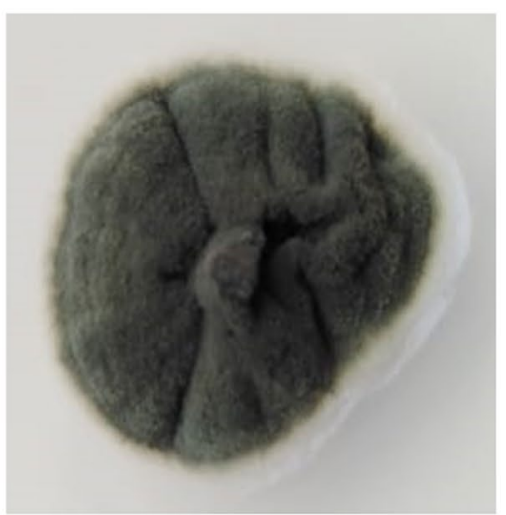

9

Figure 4. Colonies features of Cladosporium strains; (1-4): C. cladosporioides, (5-7): C. limoniforme, (8): C. ramotenellum, and (9): C. sphaerospermum.

From this study, it was observed that the main differences between the three groups of C. cladosporioides species complex, $C$. herbarum species complex and C. sphaerospermum species complex were: the colony of $C$. cladosporioides species complex was regular, feathery, white aerial mycelium sparse and diffuse, or sometimes abundantly formed. Conidia of C. sphaerospermum species complex was small as compared with the other two groups (up to $5.468 \mu \mathrm{m}$ in length) and wasn't shown septum. C. herbarum species complex was characterized by the formation of chlamydospores in both two species C. limoniforme and C. ramotenellum (which accurately identified by molecular technique).

Sequencing analysis of Cladosporium sp.. The sequences of the tested isolates with actin gene were shown 100-97\% similarity to GenBank Cladosporium depositing strains. The phylogenetic analysis dependent on the amplifying actin gene, showed differentiation between the studied isolates, and the three Cladosporium species complexes, which identified morphologically, were discriminated into four species after molecular identification. 
The phylogenic tree revealed that the strains could be categorized into four various clades, each representing one species. From the tested twenty-six isolates, nineteen strains which were grouped into C. herbarum complex in morphological characterization, here were discriminated into two species; 17 strains named as $C$. limoniforme and 2 strains $C$. ramotenellum; each species arranged in a separate clade. The first clade comprised seventeen strains of C. limoniforme (SVUCl7, SVUCl8, SVUCl9, SVUCl10, SVUCl11, SVUCl12, SVUCl13, SVUCl14, SVUCl15, SVUCl16, SVUCl17, SVUCl18, SVUCl19, SVUCl20, SVUCl21, SVUCl22 and SVUCl23) clustered together with KX239998.1 and MG680525.1 obtained from the Genbank with bootstrap 97. The second clade consisted from two strains of C. ramotenellum (SVUCr24 and SVUCr25), which clustered together with MF185921.1 and MG680539.1, which were achieved from the Genbank with bootstrap 73. The third clade formed from the single strain of C. sphaerospermum which clustered with two strains obtained from the Genbank (EF101379.1 and MF185915.1) named also as C. sphaerospermum with bootstrap 94. Six strains were belonged to the C. cladosporioides complex in morphological identification, discriminated molecularly as C. cladosporioides (SVUCc1, SVUCc2, SVUCc3, SVUCc4, SVUCc5 and SVUCc6) in the fourth clade and grouped with two strains obtained from Genbank; named as C. cladosporioides with accession numbers MG680523.1 and MN173597.1, and bootstrap value 99 (Fig. 5).

Pathogenic activity of Cladosporium sp.. The pathogenic effect of 26 strains of Cladosporium belonged to four species were tested. All the studied strains were able to cause leaf spot infections on Vicia faba leaves with different levels.

The two strains of C. ramotenellum (SVUCr24 and SVUCr25) were significant moderately virulent, which caused lesions, and infected 50-75\% of the leaves surface. Eleven strains of C. limoniforme (SVUCl7, SVUCl9, SVUCl10, SVUCl11, SVUCl12, SVUCl15, SVUCl16, SVUCl18, SVUCl19, SVUCl21 and SVUCl23) were significant moderately virulent (lesion on $50-75 \%$ of infected leaves). Two strains of C. limoniforme (SVUCl17 and SVUCl22) were significant highly virulent as the lesions appeared more than $75 \%$ of the leaf surface. The other four species of C. limoniforme (SVUCl8, SVUCl13, SVUCl14 and SVUCl20) were non-significant hypovirulent, lesions were recorded on less than $50 \%$ of infected leaves. SVUCs 26 of C. sphaerospermum also was nonsignificant hypovirulent. Five strains of C. cladosporioides (SVUCc1, SVUCc2, SVUCc3, SVUCc4 and SVUCc5) were significant moderately virulent. The other one strain of C. cladosporioides (SVUCc6) was non-significant hypovirulent (Table 2 and Fig. 6).

Inhibition growth of Cladosporium isolates by C.globosum. C. globosum clearly inhibited the growth of Cladosporium isolates in dual test plates at ranges from 12.5 to $40 \mathrm{~mm}$. The maximum inhibition growth was observed in isolate of SVUCl11, and the lowest value was noticed in SVUCl14. The growth of SVUCl8, SVUCl10 and SVUCr24 weren't inhibited by C. globosum. All isolates of C. cladosporioides were inhibited by C. globosum at levels from 14.28 to $33.33 \mathrm{~mm}$. SVUCr25 was inhibited by C. globosum at $14.28 \mathrm{~mm}$. Isolate of SVUCs26 was inhibited at $31.67 \mathrm{~mm}$ (Fig. 7).

\section{Discussion}

In this study eight species were isolated from leaves and pods of Vicia faba, they were identified by morphological and molecular methods, and the most common species in the count were Alternaria alternata and Cladosporium cladosporioides. C. oxysporum and C. sphaerospermum were recorded by Paul and $\mathrm{Yu}^{29}$; the two species of Cladosporium were isolated from the needles of pine trees (Pinus sp.) in Korea. According to Elwakil et al. ${ }^{30}$, faba bean seeds were inhabited by 13 different fungal genera, among which were Aspergillus, Penicillium, Alternaria, Botrytis, Cladosporium, Epicoccum, Fusarium, and Rhizopus. Our result has been in agreement with Saleem et al. ${ }^{31}$ who estimated that fourteen species were isolated from diseased leaves of broad bean, collected fungal species: Alternaria alternata, Cladosporium cladosporioides and C. sphaerospermum. Pszczółkowska et al..$^{32}$ reported that Alternaria alternata, Aspergillus sp. Cladosporium cladosporioides were determined among sixteen fungal species isolated from faba bean seeds harvested in the regions of Warmia and Mazury and Lower Silesia in Poland.

In this study C. cladosporioides showed morphological characteristics were in agreement and in the ranges described with Bensch et al. ${ }^{9}$ who reported that ramoconidia cylindrical-oblong, $15-50 \times 2.5-5 \mu \mathrm{m}$, with up to three septa, pale olivaceous brown. Secondary ramoconidia ellipsoid, subcylindrical to cylindrical-oblong, $7-38 \times 2-6 \mu \mathrm{m}(0-1)$ septate, occasionally with two septa. Conidia numerous, catenate, small terminal conidia obovoid, ovoid to limoniform, subglobose, 3-7 $\times 1.5-3 \mu \mathrm{m}$ aseptate, intercalary conidia limoniform, ellipsoidovoid, sometimes fusiform or subcylindrical, 5-14.5 $\times 2-4 \mu \mathrm{m}$, aseptate. In this study, it was found that the colony was more grey feathery texture formed in all C. cladosporioides isolates after five days of incubation.

C. limoniforme morphological features were shown partially similarities to those described with Bensch et al. ${ }^{11}$ who reported that colonies on PDA were smoke-grey, dark grey olivaceous to iron-grey, reverse olivaceous black to iron-grey, velvety to granular; margins broad, regular, white, glabrous to feathery; aerial mycelium diffuse, sometimes found in colony center; growth regular, flat. In this report, this species was characterized by the abundantly formation of chlamydospores and also the properties of ramoconidia and secondary ramoconidia showed differences in the size from those described by Bensch et al. ${ }^{11}$ who stated that ramoconidia 15-50 $\mu \mathrm{m}$ long, $(0-1)$ septate, base $2-3 \mu \mathrm{m}$ wide. Secondary ramoconidia subcylindrical to fusiform, ellipsoid, 8-30×2.5-4 $\mu \mathrm{m}, 0-1$ septate, pale olivaceous brown or pale brown, surface ornamentation variable, loosely verruculose, sometimes spiny or irregularly rough-walled, walls unthickened.

In this study, some of the morphological properties of $C$. ramotenellum were different from other studies: ramoconidia up to $30.313 \mu \mathrm{m}$ in length and $4.418 \mu \mathrm{m}$ in width; aseptate ramoconidia were abundantly and one septum sometimes was formed. Bensch et al. ${ }^{9}$ reported that ramoconidia were cylindrical-oblong, $0-1$ septate, rarely up to 4 septate, fluctuated between $47 \mu \mathrm{m}$ long and 2-4 $\mu \mathrm{m}$ wide. Polymorphous conidia were recorded 


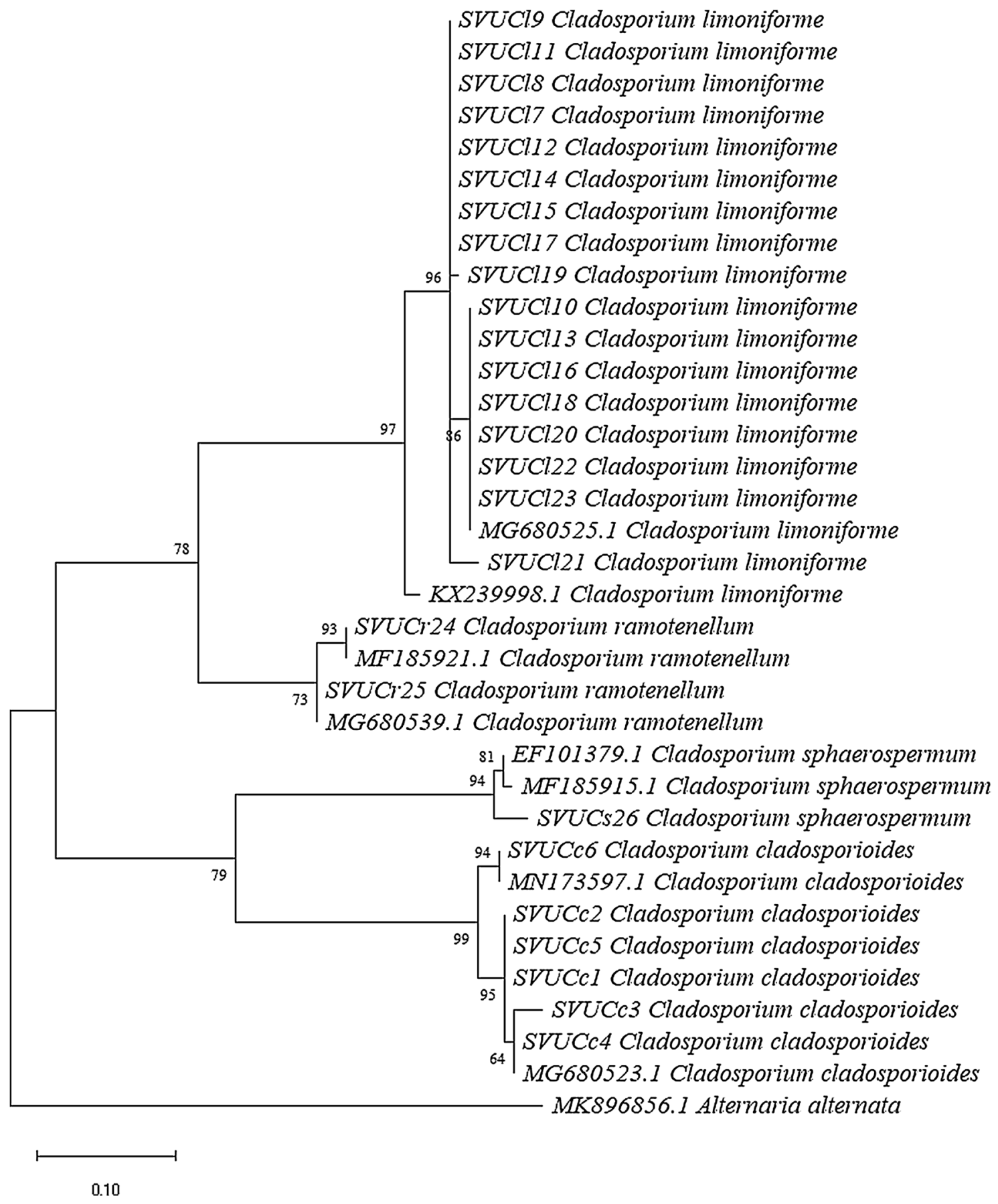

Figure 5. Maximum likelihood phylogenetic tree based on the analysis of ACT gene of the 26 Cladosporium isolates obtained from Vicia faba leaves and pods samples, with strains reference sequences achieved from the Genbank.

in this study: $4.34-10.075 \mu \mathrm{m}$ in length $\times 2.581-3.456 \mu \mathrm{m}$ in width; $0-1$ septate. Bensch et al..$^{9}$ recorded that conidia were catenate, in branched chains, straight, sometimes slightly curved, small terminal conidia numerous, globose, subglobose or obovoid or ovoid, or limoniform, 2.5-7 $\times 2-4.5 \mu \mathrm{m}$, aseptate, without distal hilum or with a single apical scar; intercalary conidia subcylindrical to ellipsoid, $8-15 \times 3-4.5 \mu \mathrm{m}, 0-1$ septate. In this study, chlamydospores were present with rarley.

Morphological characterization of C. sphaerospermum in this study partially agreed with the description obtained with Paul and $\mathrm{Yu}^{29}$ who found that conidia were spherical, ellipsoidal to cylindrical with sounded ends, with dimensions of $2.0-8.0 \times 2.0-4.0 \mu \mathrm{m}$ and secondary ramoconidia had $0-4$ septum with size were 8.5-20.0 $\times 3.0-6.0 \mu \mathrm{m}$, but in this study, conidial size were $2.797-13.047$ (length) $\times 0.959-3.955$ (width), sometimes with one septum; ramoconidial size were 11.4-27.106 (length) $\times 2.035-4.422$ (width). 


\begin{tabular}{|c|c|c|c|}
\hline Code of isolate & Isolates name & Mean of pathogenic activity & Accession number \\
\hline SVUCc1 & Cladosporium cladosporioides & $\mathrm{B}^{*}$ & MZ164887 \\
\hline SVUCc2 & C. cladosporioides & $\mathrm{B}^{*}$ & MZ164888 \\
\hline SVUCc3 & C. cladosporioides & $\mathrm{B}^{*}$ & MZ164889 \\
\hline SVUCc4 & C. cladosporioides & $\mathrm{B}^{*}$ & MZ164890 \\
\hline SVUCc5 & C. cladosporioides & $\mathrm{B}^{*}$ & MZ164891 \\
\hline SVUCc6 & C. cladosporioides & A & MZ164892 \\
\hline SVUCl7 & C. limoniforme & $\mathrm{B}^{*}$ & MZ164893 \\
\hline SVUCl8 & C. limoniforme & A & MZ164894 \\
\hline SVUCl9 & C. limoniforme & $\mathrm{B}^{*}$ & MZ164895 \\
\hline SVUCl10 & C. limoniforme & $\mathrm{B}^{*}$ & MZ164896 \\
\hline SVUCl11 & C. limoniforme & $\mathrm{B}^{*}$ & MZ164897 \\
\hline SVUCl12 & C. limoniforme & $\mathrm{B}^{*}$ & MZ164898 \\
\hline SVUCl13 & C. limoniforme & A & MZ164899 \\
\hline SVUCl14 & C. limoniforme & $\mathrm{A}$ & MZ164900 \\
\hline SVUCl15 & C. limoniforme & $\mathrm{B}^{*}$ & MZ164901 \\
\hline SVUCl16 & C. limoniforme & $\mathrm{B}^{*}$ & MZ164902 \\
\hline SVUCl17 & C. limoniforme & $\mathrm{C}^{*}$ & MZ164903 \\
\hline SVUCl18 & C. limoniforme & $\mathrm{B}^{*}$ & MZ164904 \\
\hline SVUCl19 & C. limoniforme & $\mathrm{B}^{*}$ & MZ164905 \\
\hline SVUCl20 & C. limoniforme & $\mathrm{A}$ & MZ164906 \\
\hline SVUCl21 & C. limoniforme & $\mathrm{B}^{*}$ & MZ164907 \\
\hline SVUCl22 & C. limoniforme & $\mathrm{C}^{*}$ & MZ164908 \\
\hline SVUCl23 & C. limoniforme & $\mathrm{B}^{*}$ & MZ164909 \\
\hline SVUCr24 & C. ramotenellum & $\mathrm{B}^{*}$ & MZ164910 \\
\hline SVUCr25 & C. ramotenellum & $\mathrm{B}^{*}$ & MZ164911 \\
\hline SVUCs26 & C. sphaerospermum & A & MZ164912 \\
\hline
\end{tabular}

Table 2. Codes, accession numbers, and pathogenic effects of Cladosporium strains on Vicia faba plants. Pathogenicity rating, A: hypovirulent; B: moderately virulent and C: virulent. ${ }^{\star}$ Means were significantly at $\mathrm{p}<0.05$.

Identification of Cladosporium with morphological characterization is partially difficult due to the high morphological similarities between species ${ }^{33}$. This finding was confirmed while morphological group classification was carried out. This has observed because the morphological features grouped the collected isolates into three groups; after molecular confirmation they grouped into four species, because molecular identification is more accurate and could differentiate the fungi under species level. The phylogenetic analysis was done by amplifying of actin gene. As reported with many researchers, actin gene could discriminate between species of Cladosporium ${ }^{12,13,33,34}$. In this study, three groups were observed morphologically: C. cladosporioides complex species, C. herbarum complex, C. sphaerospermum complex; they were discriminated into four species: C. cladosporioides, C. limoniforme, C. ramotenellum and C. sphaerospermum.

One hundred percent of Cladosporium strains were pathogenic by appearing of lesions to inoculated leaves of Vicia faba; 20 strains were significant and the other six strains weren't as compared with non-infected leaves. It was reported by Snyder ${ }^{35}$ that primary infection by Cladosporium develops through the soil or from the seeds, or from diseased pods that showed discoloured spots, and these when sown appeared a various percentage of infected seedlings. Surface sterilization of seeds and pods was not preventing disease. The existence of the fungus in the pods perhaps cause hair-like propagation of the inner tissue, resulting in the formation of felty and white patches extending into the pod cavity. Abdel-Motaal et al. ${ }^{36}$ reported that Cladosporium herbarum caused disease on Hyoscyamus muticus plant, firstly developed after 2 weeks as white spots, which increased and became after 3 weeks to brown. Our result has been in disagreement with Saleem et al. ${ }^{31}$ who found that Cladosporium cladosporioides and C. sphaerospermum showed negative pathogenic effects on the leaves of broad bean plants and the inoculated leaves couldn't develop any lesions. It has been proven by Temperini et al. ${ }^{34}$ the ability of $C$. herbarum complex species and C. cladosporioides complex species to cause lesions in healthy pears.

The growth of all isolates of tested Cladosporium were inhibited by C. globosum except three isolates didn't show inhibition. As reported with Wang et al. ${ }^{37}$ C. globosum had various ranging inhibitory effects on plant pathogenic bacteria and fungi. When C. globosum intersected with pathogens on the same cultured plates, plant pathogens were surrounded by it, and the margins of colonies collapsed. Chaetomium globosum colonized the nutritious space and penetrating pathogens mycelia, the pathogens stopped growing, spores were reduced in the number, abnormal branches increased, mycelial walls damaged and all cell contents released and finally die. 


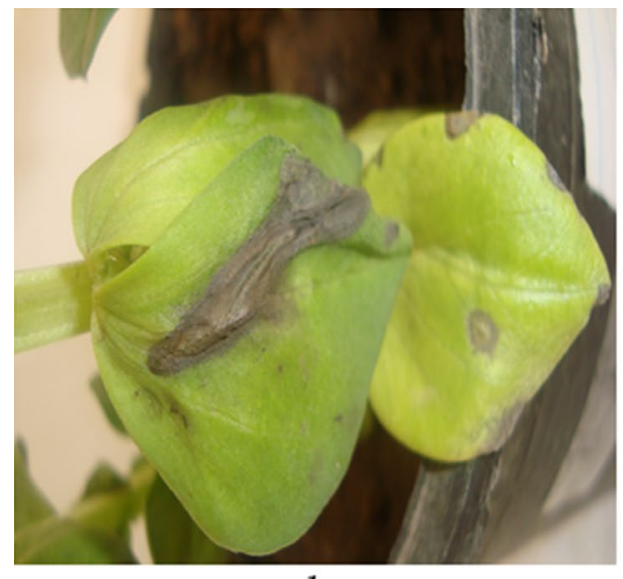

1

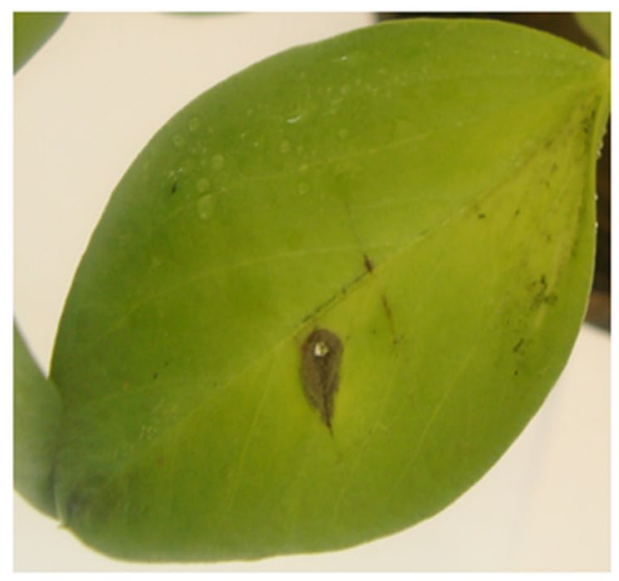

3

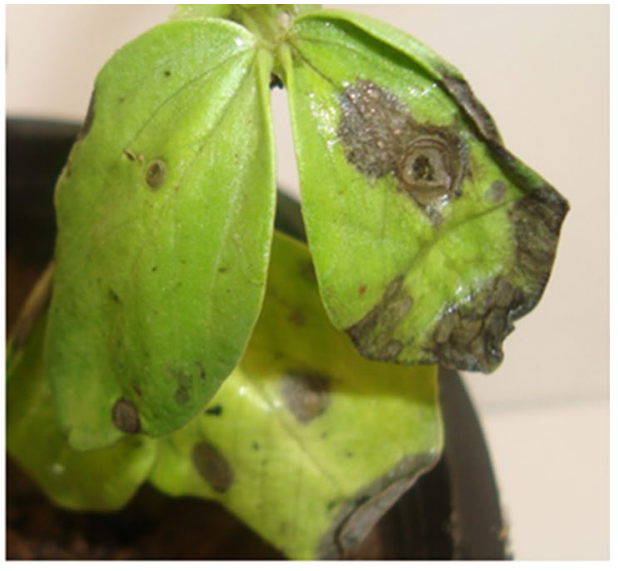

2

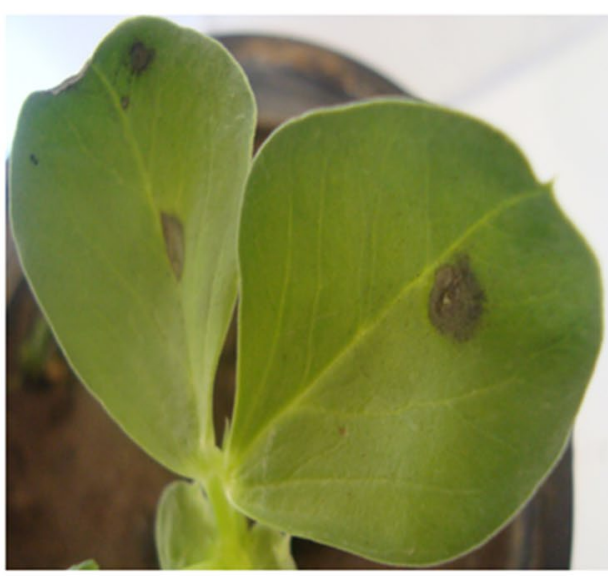

4

Figure 6. Lesions caused by Cladosporium species on leaves of Vicia faba; (1): C. cladosporioides, (2): limoniforme, (3): C. ramotenellum, and (4): C. sphaerospermum.

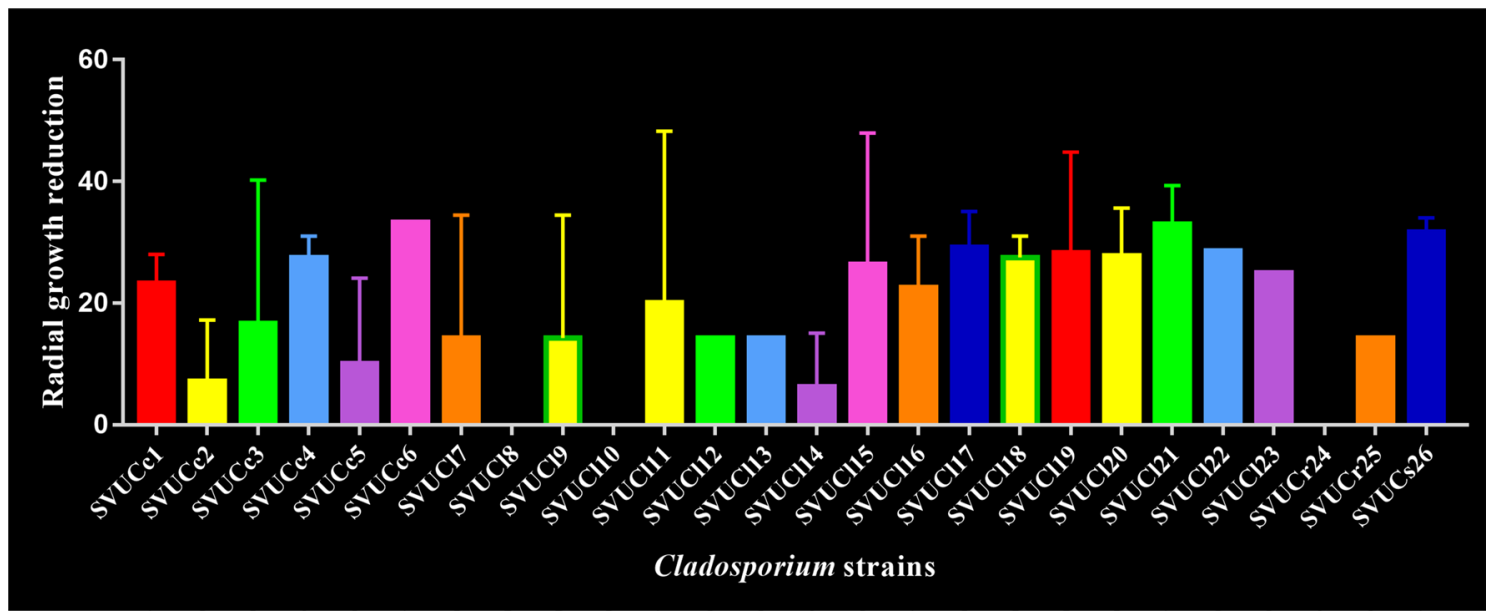

Figure 7. Inhibitory effect of C. globosum on the growth of Cladosporium strains.

\section{Conclusion}

In this study, we could prove that the genus of Cladosporium has complex species, in addition to morphological characterization, molecular sequences are required to discriminate between closely related species. The pathogenic effect of Cladosporium strains was evaluated and the using of biocontrol method to prevent its pathogenicity was determined successfully by C. globosum. 


\section{Data availability}

Sequence data have been submitted to GenBank, https://www.ncbi.nlm.nih.gov/nucleotide/, and we attached the text file sequences, the submission text bankit, also we waite the accession numbers.

Received: 15 April 2021; Accepted: 9 June 2021

Published online: 09 July 2021

\section{References}

1. El-Mansoury, M. A. M. Influence of alternative irrigation applied water on water productivity of faba bean (Vicia faba L.). Alexandria Sci. Exch. J. An Int. Q. J. Sci. Agric. Environ. 37, 679-689 (2016).

2. Ksiezzakk, J., Staniak, M. \& Bojarszczuk, J. The regional differentiation of legumes cropping area in Poland between 2001 and 2007. Pol. J. Agronom. 1, 25-31 (2009).

3. Sillero, J. C. et al. Faba bean breeding for disease resistance. Field Crops Res. 115, 297-307 (2010).

4. Kaur, S. et al. SNP discovery and high-densitygenetic mapping in faba bean (Vicia faba L.) permits identification of QTLs for ascochyta blight resistance. Plant Sci. 217, 47-55 (2014).

5. Horoszkiewicz-Janka, J., Jajor, E. \& Korbas, M. Potential risk of infection of pathogenic fungi to legumes (Fabales) and possibilities of their control. Prog. Plant Prot. 53, 762-767 (2013).

6. Jayawardena, R. S. et al. One stop shop IV: taxonomic update with molecular phylogeny for important phytopathogenic genera: 76-100 (2020). Fungal Divers. 103, 87-218 (2020).

7. Heuchert, B., Braun, U. \& Schubert, K. Morphotaxonomic revision of fungicolous Cladosporium species (hyphomycetes). Schlechtendalia. 13, 1-78 (2005).

8. El-Morsy, E. M. Fungi isolated from the endorhizosphere of halophytic plants from the red sea coast of Egypt. Fungal Divers. 5, 43-54 (2000).

9. Bensch, K., Braun, U., Groenewald, J. Z. \& Crous, P. W. The genus Cladosporium. Stud. Mycol. 72, 1-401 (2012).

10. Bensch, K. et al. Common but different: The expanding realm of Cladosporium. Stud. Mycol. 82, 23-74 (2015).

11. Bensch, K. et al. Cladosporium species in indoor environments. Stud. Mycol. 89, 177-301 (2018).

12. Bensch, K. et al. Speciesand ecological diversity within the Cladosporium cladosporioides complex (Davidiellaceae, Capnodiales). Stud. Mycol. 67, 1-94 (2010).

13. Schubert, K. et al. Biodiversity in the Cladosporium herbarum complex (Davidiellaceae, Capnodiales), with standardisation of methods for Cladosporium taxonomy and diagnostics. Stud. Mycol. 58, 105-156 (2007).

14. Zalar, P. et al. Phylogenyand ecology of the ubiquitous saprobe Cladosporium sphaerospermum, with descriptions of seven new species from hypersaline environments. Stud. Mycol. 58, 157-183 (2007).

15. Dugan, F. M., Braun, U., Groenewald, J. Z. \& Crous, P. W. Morphological plasticity in Cladosporium sphaerospermum. Persoonia 21, 9-16 (2008).

16. Braun, U. Miscellaneous notes on some cercosporoid hyphomycetes. Bibl. Lichenol. 86, 79-98 (2003).

17. Christensen, C. M. Influence of small differences in moisture content upon the invasion of hard red winter wheat by Aspergillus restrictus and A. repens. Cereal Chem. 40,385-395 (1963).

18. Abdel-Hafez, S. I. I., El-Kady, I. A., Mazen, M. B. \& El-Maghraby, O. M. O. Mycoflora and trichothecene toxins of baddy grains from Egypt. Mycopathologia 100, 103-112 (1987).

19. Abdel-Hafez, S. I. I., El-Kady, I. A., Mazen, M. B. \& El-Maghraby, O. M. O. Effect of temperature and moisture content on germination capacity of paddy grain- borne fungi from Egypt. Pure Sci. Eng. Ser. 1, 91-105 (1993).

20. Beuchat, L. R. \& Hwang, C. A. Evaluation of modified dichloran $18 \%$ glycerol (DG18) agar for enumerating fungi in wheat flour: A collaborative study. Int. J. Food Microbiol. 29, 161-166 (1996).

21. Doyle, J. J. \& Doyle, J. L. A rapid DNA isolation procedure for small quantities of fresh leaf tissue. Phytochem. Bull. 19, 11-15 (1987).

22. Carbone, I. \& Kohn, L. M. A method for designing primer sets for speciation studies in filamentous ascomycetes. Mycologia 91, 553-556 (1999).

23. Thompson, J. D., Higgins, D. G. \& Gibson, T. J. CLUSTAL W: Improving the sensitivity of progressive multiple sequence alignment through sequence weighting, position-specific gap penalties and weight matrix choice. NAR 22, 4673-4680 (1994).

24. Tamura, K., Stecher, G., Peterson, D., Filipski, A. \& Kumar, S. MEGA6: Molecular evolutionary genetics analysis version 6.0. Mol. Biol. Evol. 30, 2725-2729 (2013).

25. Tamura, K. \& Nei, M. Estimation of the number of nucleotide substitutions in the control region of mitochondrial DNA in humans and chimpanzees. Mol. Biol. Evol. 10, 512-526 (1993).

26. Berner, D. K., SmallWood, E. L., McMahon, M. B. \& Luster, D. G. First report of leaf spot caused by Cladosporium herbarum on Centaurea solstitialis in Greece. Plant Dis. 91, 463 (2007).

27. Petchkongkaew, A., Taillandier, P., Gasaluck, P. \& Lebrihi, A. Isolationof Bacillus spp. from Thai fermented soybean (Thua-nao): Screening for aflatoxin B1 and ochratoxin A detoxification. J. Appl. Microbiol. 104, 1495-1502 (2007).

28. Shi, L. et al. Ochratoxin A biocontrol and biodegradationby Bacillus subtilis CW 14. J. Sci. Food Agric. 94, 1879-1885 (2014).

29. Paul, N. C. \& Yu, S. H. Two species of endophytic Cladosporium in pine trees in Korea. Mycobiology 36, 211-216 (2008).

30. Elwakil, M. A., El-Refai, I. M., Awadallah, O. A., El-Metwally, M. A. \& Mohammed, M. S. Seed-borne pathogens of faba bean in Egypt: Detection and pathogenicity. Plant Pathol. 8, 90-97 (2009).

31. Saleem, A., El-Said, A. H. M., Maghraby, T. A. \& Hussein, M. A. Pathogenicity and pectinase activity of some facultative mycoparasites isolated from Vicia faba diseased leaves in relation to photosynthetic pigments of plant. J. Plant Pathol. Microbiol. 3, 141 (2012).

32. Pszczółkowska, A. et al. Effect of weather conditions on yield and health status of faba bean seeds in Poland. Agronomy 10, 48 (2020).

33. Sandoval-Denis, M. et al. Cladosporium species recovered from clinical samples in the United States. JCM 53, 2990-3000 (2015).

34. Temperini, C. V., Pardo, A. G. \& Pose, G. N. Diversity of airborne Cladosporium species isolated from agricultural environments of northern Argentinean Patagonia: Molecular characterization and plant pathogenicity. Aerobiologia 34, 227-239 (2018).

35. Snyder, W. C. A leaf, stem, and pod spot of Pea caused by a species of Cladosporium. Phytopathology 24(8), 890-905 (1934).

36. Abdel-Motaal, F. F., Nassar, M. M., El-Zayat, S. A., El-Sayed, M. A. \& Ito, S. Antifungal activity of endophytic fungi isolated from Egyptian henbane (Hyoscyamus muticus L.). Pak. J. Bot. 42, 2883-2894 (2010).

37. Wang, Y. et al. Inhibition effects and mechanisms of the endophytic fungus Chaetomium globosum L18 from Curcuma wenyujin. Acta Ecol. Sin. 32, 2040-2046 (2012).

\section{Author contributions}

E.G.A.E.M.E., Y.A.G. and M.A.H. wrote the main manuscript text, E.G.A.E.M.E. prepared all figures and tables. All authors reviewed the manuscript. 


\section{Competing interests}

The authors declare no competing interests.

\section{Additional information}

Supplementary Information The online version contains supplementary material available at https://doi.org/ 10.1038/s41598-021-93123-w.

Correspondence and requests for materials should be addressed to E.G.A.E.M.E.-D.

Reprints and permissions information is available at www.nature.com/reprints.

Publisher's note Springer Nature remains neutral with regard to jurisdictional claims in published maps and institutional affiliations.

(c) (1) Open Access This article is licensed under a Creative Commons Attribution 4.0 International License, which permits use, sharing, adaptation, distribution and reproduction in any medium or format, as long as you give appropriate credit to the original author(s) and the source, provide a link to the Creative Commons licence, and indicate if changes were made. The images or other third party material in this article are included in the article's Creative Commons licence, unless indicated otherwise in a credit line to the material. If material is not included in the article's Creative Commons licence and your intended use is not permitted by statutory regulation or exceeds the permitted use, you will need to obtain permission directly from the copyright holder. To view a copy of this licence, visit http://creativecommons.org/licenses/by/4.0/.

(C) The Author(s) 2021 